UDK $577.1: 61$

ISSN 1452-8258

J Med Biochem 39: 100-107, 2020

\title{
ASSESSMENT OF ABBOTT ARCHITECT 25-OH VITAMIN D ASSAY IN DIFFERENT LEVELS OF VITAMIN D
}

\author{
PROCENA ODREĐIVANJA 25-OH VITAMINA D NA ABBOTT ARCHITECT ANALIZATORU \\ PRI RAZLIČITIM NIVOIMA DEFICITA VITAMINA 25-OH D
}

\author{
Esin Avci ${ }^{1}$, Süleyman Demir ${ }^{1}$, Diler Aslan ${ }^{1}$, Rukiye Nar ${ }^{1}$, Hande Şenol $^{2}$ \\ ${ }^{1}$ Department of Biochemistry, Faculty of Medicine, Pamukkale University, Denizli, Turkey \\ ${ }^{2}$ Department of Biostatistics, Faculty of Medicine, Pamukkale University, Denizli, Turkey
}

\section{Summary}

Background: There is increasing requests of Vitamin D test in many clinical settings in recent years. However, immunoassay performance is still a controversial topic. Several diagnostic manufacturers have launched automated 25-hydroxyvitamin D (25-OH D) immunoassays in the past decade. We compared the performance of Abbott Architect 25-OH D Vitamin immunoassay with liquid chromatography-tandem mass spectrometry systems (LC$\mathrm{MS} / \mathrm{MS}$ ) to evaluate immunoassay performance, especially in deficient groups.

Methods: Eighty human serum samples were analyzed with Architect 25-OH D vitamin kit (Abbott Diagnostics, Lake Forest, IL, USA) and LC-MS/MS systems (Zivak Technology, Istanbul, Turkey). The results of the immunoassay method were compared with the LC-MS/MS using Passing-Bablok regression analysis, Bland-Altman plots and correlation coefficient analysis. We also evaluated results in four levels of D vitamin as a severe deficiency, deficiency, insufficiency, and sufficiency.

Results: Architect showed $9.59 \%$ bias from LC-MS/MS with smaller mean. Passing-Bablok regression analysis demonstrated the value of 0.95 slope and had a constant bias with an intercept value of -4.25 . Concordance correlation coefficient showed moderate agreement with the value of 0.918 (95\% Cl 0.878-0.945). Two methods revealed

\section{Kratak sadržaj}

Uvod: Poslednjih godina povećan je zahtev za određivanjem vitamina $D$ u mnogim kliničkim slučajevima. Međutm, imunoodređivanje je i dalje kontraverzno. Nekoliko dijagnostičkih proizvođača razvilo je poslednjih godina automatsko imunoodređivanje 25-hidroksivitamina D (25-OH D). Mi smo poredili imunohemijsko određivanje $25-\mathrm{OH}$ vitamina $\mathrm{D}$ pomoću Abbott Architect analizatora sa tandem sistemom tečna hromatografija-masena spektrometrija (LS-MS/MS) kako bi procenili imunohemijsko određivanje naročito u deficijentnim grupama.

Metode: Analizirano je 80 humanih uzoraka seruma primenom Architect 25-OH D vitamin reagensom (Abbott Diagnostics, Lake Forest, IL, USA) i LC-MS/MS (Zivak Technology, Istanbul, Turkey). Dobijeni rezultati primenom imunoodređivanja bili su u korelaciji sa rezultatima dobijenim sistemom tečna hromatografija-masena spektrometrija (LSMS/MS) korišćenjem Passing-Bablok regresionom analizom, Bland-Altman metodom i analizom korelacionog koeficijenta. Takođe smo procenjivali rezultate četiri nivoa vitamina D kao tešku deficijenciju, deficijenciju, insuficijenciju i suficit. Rezultati: Arhitect je prikazao 9,59\% odstupanje od LC MS/MS sa neznatnim značajem. Passing-Bablok regresiona analiza ukazala je na vrednost nagiba od 0,95 i konstantom Korelacioni koeficijent se umereno slagao sa vrednostima 0,918 (95\% Cl 0,878-0,945). Dve metode su imale dobro

Address for correspondence:

Esin Avci

Pamukkale University, Faculty of Medicine, Medical Biochemistry Department, Denizli, Turkey e-mail: hekimesin@gmail.com 
good interrater agreement (kappa $=0.738)$. While the smallest bias determined in deficiency $(9.95 \%)$ group, the biggest was in insufficiency (15.15\%).

Conclusions: Architect 25-OH D vitamin immunoassay can be used in routine measurements but had potential misclassification of vitamin D status in insufficient and deficient groups. Although there are recent standardization attempts in 25-OH D measurements, clinical laboratories must be aware of this method.

Keywords: vitamin D, method comparison, deficiency, insufficiency, 25-Hydroxyvitamin D

\section{Introduction}

Vitamin D deficiency is a worldwide health problem caused mainly by insufficient exposure to sunlight and dietary consumption (1). It is affecting more than one billion people, especially prevalent among elderly with the several clinical findings such as muscle weakness, orthostatic hypotension, eczema etc. (2). Some studies suggested that Vitamin D deficiency were related to rheumatologic and autoimmune diseases, cancer and the other clinical conditions $(3,4)$.

Chemiluminescence immunoassays (CLIA), radioimmunoassay (RIA), high performance liquid chromatography (HPLC) and liquid chromatographytandem mass spectrometry (LC-MS/MS) are the most common techniques used for measuring of vitamin $D$ (5-6).

National Health and Nutritional Examination Survey (NHANES) recommended LC-MS/MS as the best method for quantifying vitamin $D$ metabolites due to improved sensitivity, accuracy, and reproducibility (7). Although LC-MS/MS is not simple to use, inherit some limitations; those are high costly requirement specifications, complex assay procedures, requiring of an experienced analyst. LC$M S / M S$ is still the advanced method in determining $D$ vitamin status, hence the new methods have more technique restrictions (8-9).

Serum 25-hydroxyvitamin D (25-OH D) levels have been determined by using Chemiluminescent Immunoassay (CLIA) in the recent years. It is simple, cost and time-effective method when compared to LC-MS/MS systems (6). The main limitation of immunochemical methods is the cross reactivity of the antibodies used in the assay. This method has an inability to discriminate the D2 and D3 forms of the 25-OH D metabolite (9).

Vitamin D Standardization Program (VDSP) (10) is an international effort collaborated with many constitutions etc. Central Disease Center (CDC), National Institute of Standards and Technology (NIST), NHANES, Belgian Laboratory for Analytical Chemistry, Faculty of Pharmaceutical Sciences, slaganje (kappa $=0,738)$. Najmanje odstupanje je određeno u grupi sa deficijencijom $(0,95 \%)$, a najveće u grupi sa insuficijencijom $(15,15 \%)$.

Zaključak: Imunodređivanje sa Arhitect 25-OH D vitaminom može da se koristi kao rutinsko merenje ma da ima potencijalni nedostatak pri klasifikaciji statusa vitamina $D$ u grupama sa insuficijencijom i deficijencijom. Ma da postoje skorašnji pokušaji standardizacije merenja 25-OH D kliničke laboratorije moraju ovo da imaju na umu.

Ključne reči: vitamin, poređenje metoda, deficijencija, insuficijencija, 25-hiodroksivitamin D

Ghent University (11). One of the objectives of VSDP is standardize $25-\mathrm{OH}$ D assays with NIST traceable measurement procedures (12). Standard reference materials (SRM) 2972 and 972 has been recommended for improving traceability and harmonization of $25-\mathrm{OH}$ vitamin D measurement $(10,12)$.

Recently, Abbott diagnostic claimed, their 25$\mathrm{OH}$ Vitamin D kit could determine 25(OH) Vitamin D metabolites, with excellent accuracy and sensitivity. This kit also calibrated against NIST SRM 2972. Some studies in literature, investigate the verification of Architect 25-OH Vitamin D assay (Catalog no: 3L52-25, 510k Abbott) (13-15). In the present study, we aim to compare NIST traceable Architect 25-OH Vitamin D assay with LC-MS/MS systems. To the best of our knowledge in the literature there is not any study evaluated these methods in different levels of Vitamin D. For further examination, immunoassay performance evaluated in severe deficiency/deficiency/insufficiency/sufficiency groups.

\section{Material and Methods}

\section{Serum specimens}

We randomly chosen 80 serum specimens from the patients' samples pool during four days period. The sample consisted of 40 male and 40 female, with a mean age of $50 \pm 16.4$ years, ranging from 18 to 83 years old without any chronic diseases. Serum specimen aliquot into three parts. First part was measured with Architect 25-OH D immunoassay. Within $24 \mathrm{~h}$ period, second and third parts were analyzed with LC-MS/MS methods in another laboratory. All samples stored at $-80{ }^{\circ} \mathrm{C}$ until the transfer period. While transferring period, sun exposure and heating avoided. There was not any calcium/phosphor metabolism defect. One patients' sample was excluded who received vitamin D supplement. The NonInterventional Medical Ethical Committee of Pamukkale University of Faculty of Medicine approved the study protocol. 


\section{Architect 25-OH D immunoassay}

Immunochemical assays analyzed on Abbott Architect i-2000 (Abbott Park, IL, USA). The original Architect (Abbott Diagnostics, Lake Forest, IL, USA) $25-\mathrm{OH}$ Vitamin D assay determine $25(\mathrm{OH})$ D2 and D3 in human serum and plasma. It is a delayed one-step immunoassay including a sample pre-treatment for the quantitative determination of vitamin $D$ in competitive chemiluminescent microparticle immunoassay (CMIA) technology with flexible assay protocols. This chemiflex method was used microparticles coated with anti-vitamin D lgG antibody, and biotinylated Vitamin D antibiotin IgG acridinium-labelled conjugated complex. Architect 25-OH Vitamin D 5p02 calibrators (16) were standardized against NIST SRM 2972 and traceable to the LC-MS/MS Vitamin D reference measurement procedure (University of Ghent). In Architect kit insert, limit of blank (LOB), limit of detection (LOD), limit of quantitation (LOQ) and reportable range of the assay were given as $4,5.5,6,8.5-389.75 \mathrm{nmol} / \mathrm{L}$ respectively (16).

\section{Zivak LC-MS/MS Multitasker LC-MS/MS system}

LC-MS/MS analysis were performed in Zivak Multitasker Fully Automated Sample Preparation and Injection System coupled to a MS detector. This spectrometer equipped with a Macherey-Nagel Nucleoder C18 Gravity column (125×2 mmi.d., 5 um particle size). This system can report patient data within 6 minutes including the solid phase extraction (SPE) and sample preparation and mass spectrometry analysis time. Gören et al. (17) has been verified this method, and determined uncertainties in 2015. After verification and standardization of this method started to use in routine laboratory analysis. Certified standard reference material SRM 972a was used to monitor the LC-MS/MS traceability. Sample Chromatograms and validation results for Zivak LCMS/MS Multitasker LC-MS/MS system were given at Figure 1 and Table $I$.
Table I Diagnostic performance characteristics of Zivak 25$\mathrm{OH}$ Vitamin D2/D3 LC-MS/MS Analysis Kit.

\begin{tabular}{|l|c|c|}
\hline & $\begin{array}{c}25-\mathrm{OH} \\
\text { Vitamin D3 }\end{array}$ & $\begin{array}{c}25-\mathrm{OH} \\
\text { Vitamin D2 }\end{array}$ \\
\hline LOD (nmol/L) & 3.7 & 2.65 \\
\hline LOQ (nmol/L) & 12.25 & 8.75 \\
\hline Accuracy (\%) & 94.7 & 96.4 \\
\hline $\begin{array}{l}\text { Intra-assay precision } \\
\% C V)\end{array}$ & 2.16 & 4.6 \\
\hline $\begin{array}{l}\text { Inter-assay precision } \\
\text { \%CV) }\end{array}$ & 2.74 & 4.74 \\
\hline Linearity (R2) & $0-200(0.993)$ & $0-200(0.992)$ \\
\hline
\end{tabular}

\section{Measurement comparison}

Method comparison was designed according to CLSI EP09-A3 guideline. Inter-assay imprecision of the Architect 25-OH D assay was estimated according to CLSI EP15-A3 guidelines by measuring three levels commercial quality control samples during 5 days with five replicates per day $(n=25)$. Intra- assay imprecision estimation was conducted on measuring five replicates on the same day. We determined trueness via Biorad External Quality System running three sample from different levels. We determined severe deficiency/deficiency/insufficiency/sufficiency as 0 25, 25-50, 50-75, >75, respectively (nmol/L) (4, 17-19).

\section{Statistical Analysis}

Concordance correlation analysis, PassingBablok regression analysis, Box Whisker graphics and the Bland-Altman method were performed to determine agreement between two methods. Lin's concordance correlation coefficient for continuous data and Kappa interrater agreement for categorical data was

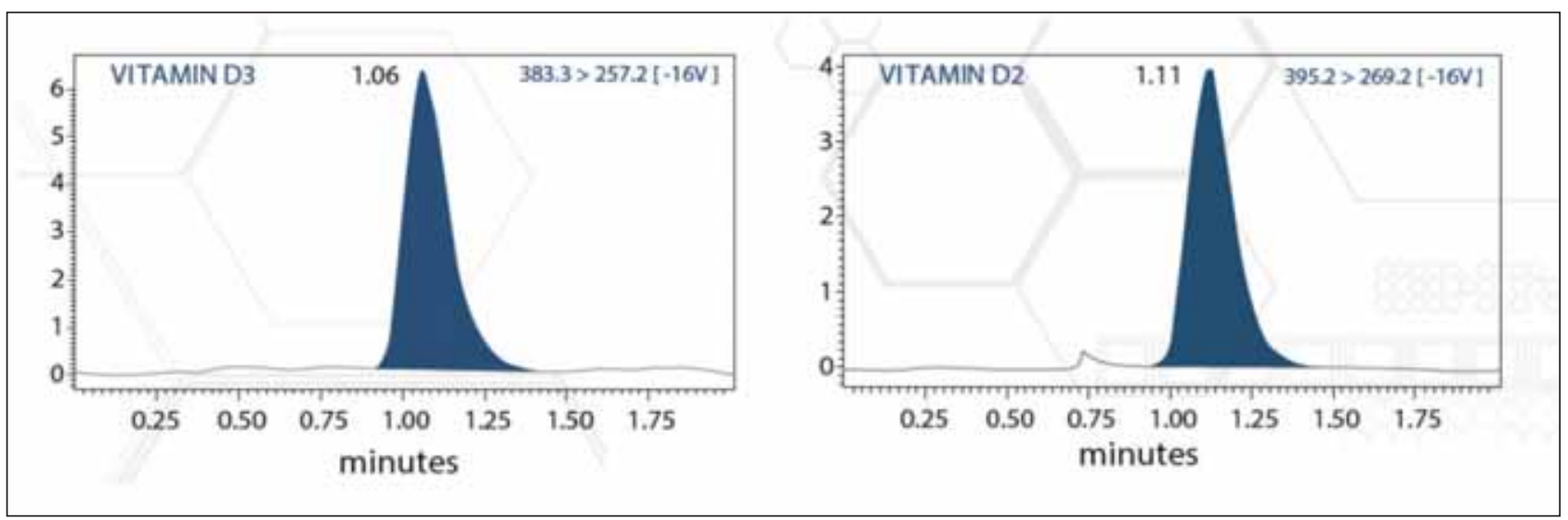

Figure 1 Sample Chromatograms of Zivak 25-OH Vitamin D2/D3 LC-MS/MS Analysis Kit. 
used to determine consistency of two methods $(\kappa<$ 0.4 poor, 0.4-0.70 fair to good, and $>0.70$ excellent agreement). The level of statistical significance was set at $p \leq 0.05$. Statistical analysis was performed using SPSS v.24.0 for Windows (SPSS Inc., Armonk, NY, USA), R (version 3.4.3, Vienna, Austria) in R Studio (Version 1.1.463 - (C) 2009-2018 RStudio, Inc.). Packages used for the analysis were $\mathrm{mcr}$ and epiR $(20,21)$.

\section{Results}

We studied 80 samples by two methods within 48-hour period. The median value of $25-\mathrm{OH} \mathrm{D}$ (2.5-97.5 percentiles; $\mathrm{nmol} / \mathrm{L})$ of eighty samples $37.75 \mathrm{nmol} / \mathrm{L}(9.68-139.7 \mathrm{nmol} / \mathrm{L})$, and 45 $\mathrm{nmol} / \mathrm{L}(12.86-126.16 \mathrm{nmol} / \mathrm{L})$ based on the values obtained from the immunoassay, and LCMS/MS systems. Box and whisker plots show the distribution of results for the two methods in Figure 2. At three concentration of 25-OH D internal quality control inter-assay CV\% was $4.9 \%, 3.0 \%$, and $2.4 \%$ and intra-assay CV\% was $1.5 \%, 1.1 \%$, and $1.0 \%$. Deviation percent results from the three external quality reports were $-4.2 \%, 8.6 \%$ and $-0.9 \%$. Architect 25-OH D Vitamin assay deviated negatively from gold standard (11.5\%). Architect 25-OH D vitamin assay demonstrated a good correlation with the results obtained with the LC-MS/MS method $\left(r^{2}=0.871, p<0.001\right)$.

The Passing-Bablok regression analyses for immunoassay against LC-MS/MS system shown in Figure 3. Architect 25-OH D assay deviated from the linearity with the value of 0.95 slope and had a constant bias with an intercept value of - 4.25 (Table II).

Bland-Altman plots for all results and four groups were given in Figure 4-5 A-B-C-D. The first one was for all sample results. The other four graphics for four different Vitamin D level groups. Architect $25-\mathrm{OH}$ showed $9.59 \%$ bias when compared to LCMS/MS system. Agreement between two methods under the four levels of $25-\mathrm{OH}$ D vitamin were given in Table III. Classified results under four headings revealed biases as 11.43\%, 9.95\%, 15.5\%, $-5.82 \%$ for severe deficiency, deficiency, insufficiency and suf-

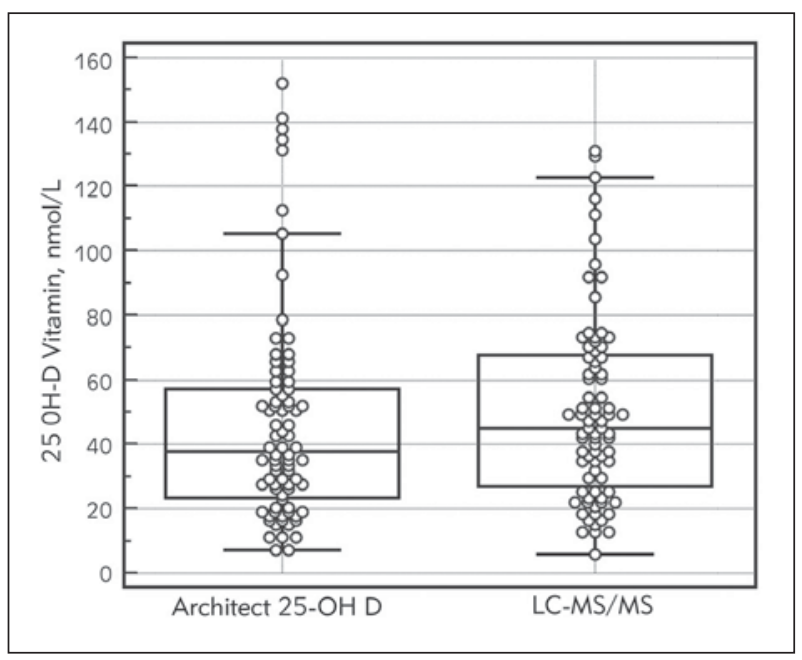

Figure 2 Box and whisker plots of LC-MS/MS and Architect 25-OH D assay for 25-OH D measurements.. Each box shows 25 to 75 percentile range. Horizontal line in each box represents group median.

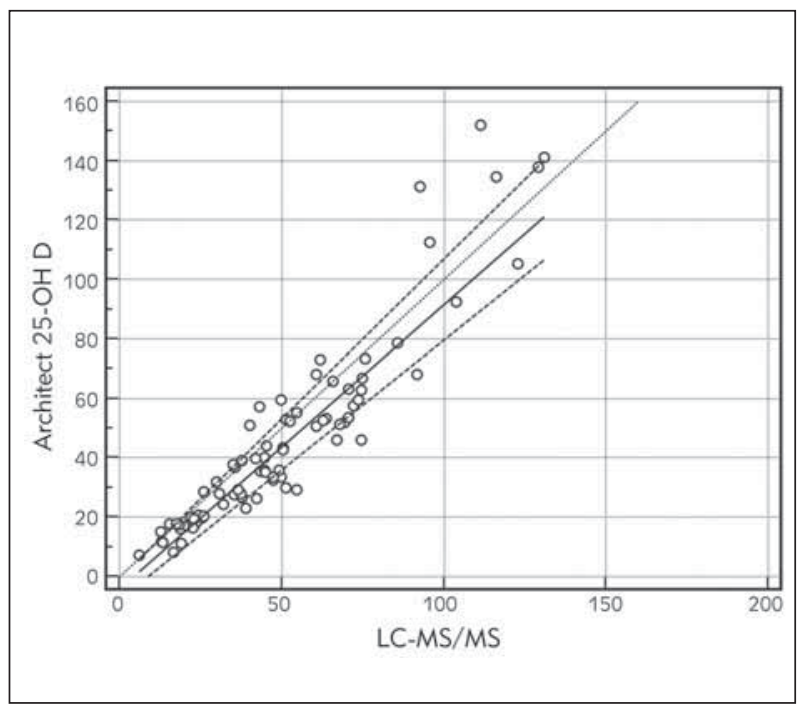

Figure 3 Passing-Bablok regression analysis of Architect 25$\mathrm{OH} \mathrm{D}$ immunoassay compared to LC-MS/MS. The regression equation is presented as $y=a+b x, y=-4.2512+0.9575 x$. Significant deviation from linearity $(P<0.05)$.

Table II Method comparison results of immunoassay for Architect 25-OH D measurement with LC-MS/MS.

\begin{tabular}{|c|c|c|c|c|c|c|c|}
\hline \multirow{2}{*}{ Method } & \multicolumn{2}{|c|}{$\begin{array}{c}\text { Passing-Bablok } \\
\text { Regression Analyses }\end{array}$} & \multicolumn{3}{|c|}{$\begin{array}{c}\text { Concordance Correlation } \\
\text { Analyses }\end{array}$} & $\begin{array}{c}\text { Bland-Altman } \\
\text { Analyses }\end{array}$ & $\begin{array}{c}\text { Interrater } \\
\text { agreement }\end{array}$ \\
\cline { 2 - 8 } & Slope & Intercept & $\mathrm{CCC}(\mathrm{Cl})$ & $\mathrm{P}$ & $\mathrm{Cb}$ & Bias (\%) & Kappa (Cl) \\
\hline LC-MS/MS & $0.95+(0.87-1.07)$ & $\begin{array}{c}-4.2512 \\
(-7.54-0.55)\end{array}$ & $\begin{array}{c}0.918 \\
(0.878-0.945)\end{array}$ & 0.934 & 0.983 & 9.59 & $\begin{array}{c}0.738^{*} \\
(0.604-0.848)\end{array}$ \\
\hline
\end{tabular}

+Significant deviation from linearity $(\mathrm{p}<0.05)$, CCC: Concordance correlation coefficient, $+p<0.05$ Cb: bias correction factor (accuracy). 


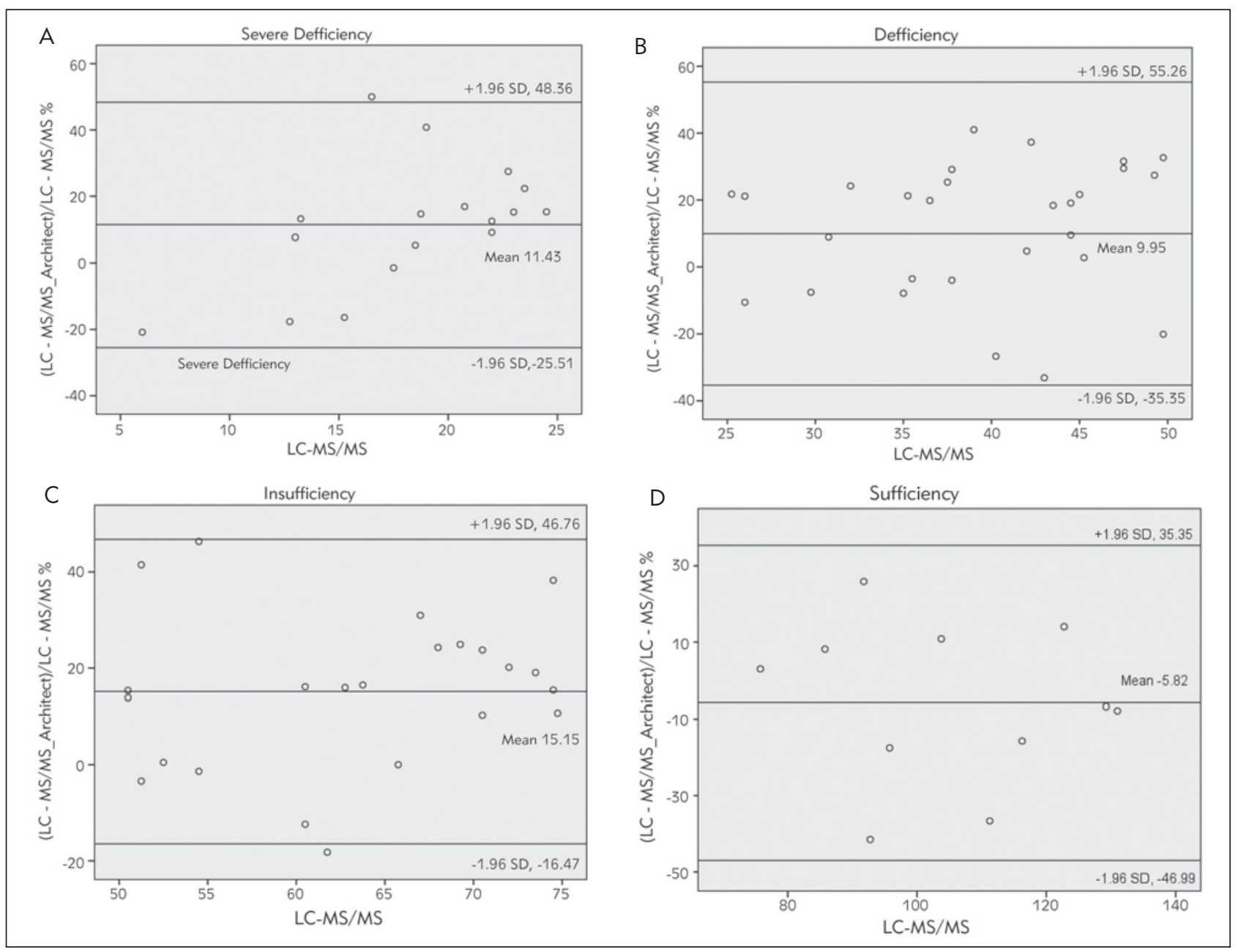

Figure 4 Bland-Altman plots of Architect 25-OH D and LC-MS/MS measurements for four different groups. Mean (thick solid line) - percentage bias (means of paired differences). Dashed lines demonstrate the $95 \%$ limits of agreement (bias \pm 1.96 standard deviation).

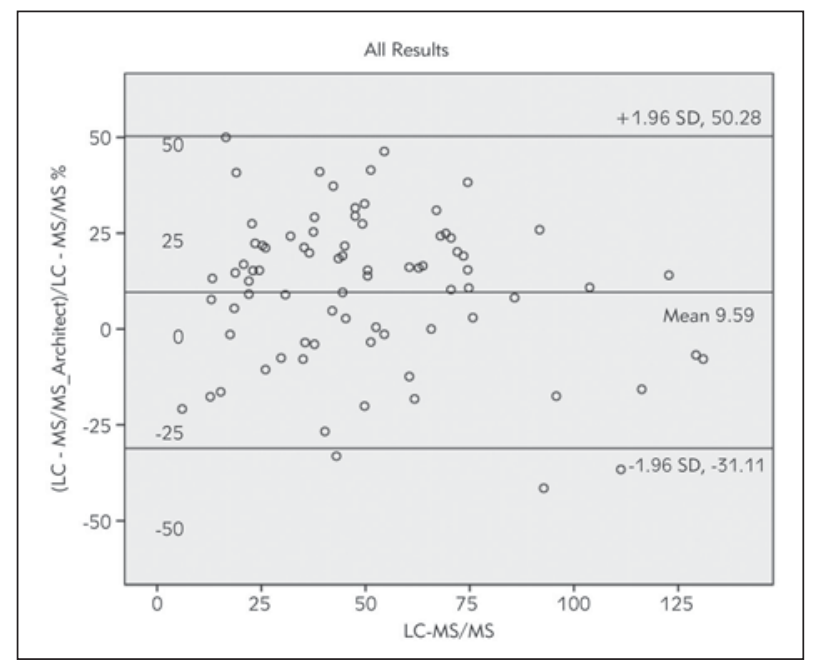

Figure 5 Bland-Altman plots of Architect 25-OH D and LCMS/MS measurements for all results. Mean (thick solid line) - percentage bias (means of paired differences). Dashed lines demonstrate the $95 \%$ limits of agreement (bias \pm 1.96 standard deviation). ficiency groups respectively. However, one of them was $<\% 5$ that VSDP recommended. Concordance correlation analyses showed moderate agreement with LC-MS/MS with 0.918 concordance coefficient ( $95 \% \mathrm{Cl}, 0.87$ to 0.94 ). Precision between two methods was 0.93 with the 0.98 corrected bias factor. Kappa coefficients of interrater agreement was found $0.738(95 \% \mathrm{Cl} 0.604-0.848)$ indicated excellent agreement. Method comparison data were shown in Table II.

\section{Discussion}

Architect 25-OH D vitamin assay revealed excellent precision with a total coefficient of variance (CV $\%)<5 \%$. When we compared to LC-MS/MS as the reference method, NIST traceable immunoassay showed a higher $r$-value $\left(r^{2}=0.871\right)$ and a proportional bias (9.59\%). Nonetheless, Architect 25-OH D vitamin assay revealed moderate agreement based on the value CCC (0.918). Two method showed excel- 
Table III Agreement between two methods under the four levels of 25-OH D vitamin.

\begin{tabular}{|c|c|c|c|c|c|c|}
\hline & \multicolumn{5}{|c|}{$\begin{array}{l}\text { Architect 25-OH D Vitamin Assay } \\
\text { Number of samples (percentage \%) }\end{array}$} \\
\hline & & $\begin{array}{c}\text { Severe } \\
\text { deficiency }\end{array}$ & Deficiency & Insufficiency & Sufficiency & Sum \\
\hline \multirow{2}{*}{$\begin{array}{l}\text { LC-MS/MS } \\
\text { system }\end{array}$} & Severe deficiency & $17(21.3 \%)$ & - & - & - & $17(21.3 \%)$ \\
\hline & Deficiency & $4(5.1 \%)$ & $21(26.6 \%)$ & $3(3.8 \%)$ & - & $28(35.5 \%)$ \\
\hline \multirow{3}{*}{$\begin{array}{l}\text { Number of } \\
\text { samples } \\
\text { (percentage \%) }\end{array}$} & Insufficiency & - & $6(7.6 \%)$ & 17 (21.5\%) & - & $23(29.1 \%)$ \\
\hline & Sufficiency & - & - & $2(2.5 \%)$ & 9 (11.4\%) & $11(13.9 \%)$ \\
\hline & Sum & 21 (26.4\%) & 27 (34.2\%) & 22 (27.8\%) & 9 (11.4\%) & 79 (100\%) \\
\hline
\end{tabular}

Kappa coefficient: 0.738; Standard error: $0.062 p=0.000$

lent agreement; kappa $=0.738$. In terms of biases immunoassay deviated negative when compared to LC-MS/MS.

Many immunoassays are suitable to determine $25-\mathrm{OH}$ D3 form. Cross reaction between total $25-\mathrm{OH}$ $\mathrm{D}$ and 25-OH D2 is the major problem (6). In Abbott kit insert manufacturer claimed $25-\mathrm{OH}$ D vitamin concentrations, at the level of $51.5 \mathrm{nmol} / \mathrm{L}$ assay has $80.5 \%$ and with the level of $140 \mathrm{nmol} / \mathrm{L}$ assay has $82.4 \%$ cross reactivity with $25-\mathrm{OH}$ D2 (15). Abbott $25-\mathrm{OH}$ D has $100 \%$ cross reactivity with $25-\mathrm{OH}$ D3. However, failure to detect the 25-OH D2 form is not an important issue in our country, hence the supplements mostly used do not contain Vit D2. Anyway, we could not detect measurable amounts of 25-OH D2 in any patients' sera. This issue might be a problem in France or USA, because of treating $D$ vitamin deficiency with D2 supplements (14). Probability of 3-epi25-OH D3 epimers- presence in the pediatric population (22), we did not include children and patients given $\mathrm{D}$ vitamin treatment in this study. On the other hand, both immunoassay and LC-MS/MS cannot separate 3-epi-25(OH) D3 epimer from the D3 form, so negative bias for immunoassay systems cannot be explained on the 3-epimer contribution (14).

In the literature, immunoassay methods showed good agreement when compared reference methods, however revealed negative biases likely our study (11, 14, 22). Annema et al. (15) reported, Architect assay showed a good correlation ( $r=0.901)$ in both vitamin D-insufficient and vitamin D-supplemented subjects when compared to the LC-MS/MS method, but had negative biases (17.4\% and $8.9 \%$, respectively). Madenci (11) and Ozcan (23) revealed different negative biases for Access immunoassay system (-19.2\% and $-2.9 \%$ respectively), but had good concordance $(0.901,0.952)$ with LC-MS/MS systems. Topçuoğlu and her colleagues (24) found $r$ and CCC value 0.957 and 0.916 with the bias of $9.5 \%$ for Access Total 25(OH) Vitamin D immunoassay on the Beckman Coulter Unicel DXI 800 analyzer.
Different from previous studies, we classified our results under four categories as; severe deficiency (< $25 \mathrm{nmol} / \mathrm{L})$, deficiency (26-50 nmol/L), insufficiency (51-75 nmol/L and sufficiency ( $>75 \mathrm{nmol} / \mathrm{L})$ (1819). While the smallest bias between Architect 25 $\mathrm{OH} \mathrm{D}$ and LC-MS/MS system was in deficiency group (9.95\%), the biggest was determined in insufficiency group (15.15\%) (Figure 5C). Architect 25-OH D vitamin assay determine some sufficient samples in insufficient area. This might lead unnecessary treatment for patients. However, World Health Organization (WHO) defined vitamin D insufficiency as serum 25$\mathrm{OH} D$ is below $50 \mathrm{nmol} / \mathrm{L}$ (25). Some studies show a large variance in the plateau level of $\mathrm{PTH}$, ranging from a serum $25-\mathrm{OH}$ D of $45 \mathrm{nmol} / \mathrm{L}$ to $75 \mathrm{nmol} / \mathrm{L}$ (19). Lack of PTH test as a limitation of our study, sufficiency cut-off was taken as $75 \mathrm{nmol} / \mathrm{L}$ (26). Some experts recommended deficiency cut-off should be taken as $<50 \mathrm{nmol} / \mathrm{L}$, based upon evidence related to bone health. Because of the necessity in older adults to minimize the risk of falls and fracture, the others suggested $<75 \mathrm{nmol} / \mathrm{L}$ as the deficiency cutoff (27). We divide $<75 \mathrm{nmol} / \mathrm{L}$ results into three groups, to take the attention capability of immunoassay detection in these groups. Based on the LCMS/MS data, $8.9 \%$ in deficiency, $7.6 \%$ of insufficiency, and $2.5 \%$ of sufficiency group data were misclassified as having vitamin $D$ deficiency by the Architect 25-OH D vitamin immunoassay (Table III).

Annema et al. (15) revealed negative bias (-17.2\%) for new restandardized Abbott Architect 25$\mathrm{OH}$ Vitamin $\mathrm{D}$ assay, on the Vitamin $\mathrm{D}$ deficiency population. Nevertheless, Annema gave proportional small bias in the Vitamin D supplementation group. Evaluation of Abbott 25-OH D assay against LCMS/MS system, Cavalier et al. (28) has evaluated; immunoassay showed good agreement with the bias of $-3.2 \%$ ( \pm 1.96 SD 8.6 to -15.1$)$. Both two studies dwelled on the misdiagnosis of Architect immunoassay systems in the deficiency groups similar to our study. 
In our study, we pointed out NIST traceable Architect 25-OH D assay failed to diagnose deficiency and insufficiency. This issue might be a problem in several clinical conditions such as osteoporosis, osteomalacia etc. Recently, Cavalier et al. (29) reported the analytical and clinical validation of new developed Abbot Architect 25-OH D assay named as „5P02«. They revealed the new standardized 5P02 clearly improved diagnosis especially in osteoporotic patients and in patients from the intensive care unit.

LC-MS/MS is still currently the best method for the precise quantification of $25-\mathrm{OH} \mathrm{D3}$ and $25-\mathrm{OH}$ D2 (9).

However, reported in literature the LC-MS/MS systems have some major problems as matrix related issues, analytical, instrumental, epimeric and isobaric interferences. Insufficiency in separating epimers and isobars resulted in overlapping with Vitamin D metabolites in chromatograms (30). Accuracy of LCMS/MS systems were performed by DEQAS with the acceptable biases varied from $-8.9 \%$ to $1.9 \%$ in our study. In the DEQAS reports we could see a large discrepancy of CV\% for LC-MS/MS systems varied from

\section{References}

1. Sahota $O$. Understanding vitamin D deficiency. Age and Ageing 2014; 43(5): 589-91.

2. Marijn M Speeckaert, Reinhart Speeckaert, Nanja van Geel, Joris R. Delanghe. Chapter One - Vitamin D Binding Protein: A Multifunctional Protein of Clinical Importance, Editor(s): Gregory S. Makowski, Advances in Clinical Chemistry, Elsevier, Volume 63, 2014: 1-57.

3. Clarke NM, Page JE. Vitamin D deficiency: a paediatric orthopaedic perspective. Current Opinion in Pediatrics: 2012; 24 (1): 46-9.

4. Damiati S. A Pilot Study to Assess Kidney Functions and Toxic Dimethyl-arginines as Risk Biomarkers in Women with Low Vitamin D Levels. J Med Biochem 2019; 38; 142-52.

5. Kiani A, Abedini A, Adcock MI, Mirenayat SM, Taghavi K, Mortaz E, Kazempour-Dizaji M. Association between vitamin $\mathrm{D}$ deficiencies in sarcoidosis with disease activity, course of disease and stages of lung involvements. J Med Biochem 2018; 37: 103-9.

6. Farrell CJL, Martin S, McWhinney B, et al. State-of-the-art vitamin $D$ assays: A comparison of automated immunoassays with liquid chromatography-tandem mass spectrometry methods. Clin Chem 2012; 3(58): 531-42.

7. Dietrich A, Volmer L. Analysis of Vitamin D Metabolic Markers by Mass Spectrometry: Current Techniques, Limitations of the 'Gold Standard' Method, and Anticipated Future Directions. Mass Spectrom Rev 2015; 34: 2-23.

8. Atef SH. Vitamin D Assays In Clinical Laboratory: Past, Present and Future Challenges. J Steroid Biochem Mol Biol 2018; 175: 136-7.
$2 \%$ to $10.6 \%$. Biases for Architect $25-\mathrm{OH} \mathrm{D}$ vitamin assay from the EQAS external quality program were $-12.2 \%,-8.6 \%$ and $-0.9 \%$ during three month period.

Based on the present study findings, Architect $25-\mathrm{OH}$ D vitamin assay can be used in routine 25 $\mathrm{OH} \mathrm{D}$ measurements, still properly making the diagnosing of patients' status. Standardization efforts in improving immunoassay techniques do not seem to contribute too much to clinical diagnosis. Especially, in deficient/insufficient samples, laboratory experts should be aware of the misinterpretation of results. Our study offered an insight into $D$ vitamin deficiency analyzing and further examinations.

Acknowledgements. The authors would like to thank Mrs. Şule YALÇIN, local representative of Dolunay Diagnostics, for her support and contributions.

\section{Conflict of interest statement}

The authors stated that they have no conflicts of interest regarding the publication of this article.

9. Grebe SKG, Singh RJ, LC-MS/MS in the Clinical Laboratory - Where to From Here? Clin Biochem Rev 2011; 32(1): 5-31.

10. Stepman HCM, Vanderroost A, Van Uytfanghe K, et al. Candidate reference measurement procedures for serum 25-hydroxyvitamin D3 and 25-hydroxyvitamin D2 by using isotope-dilution liquid chromatography-tandem mass spectrometry. Clin Chem 2011; 57(3): 441-8.

11. Madenci Çakır Ö, A Orçun, Yıldız Z, Sirmali R. Evaluation of new Beckman Coulter 25(OH) Vitamin D assay and potential improvement of clinical interpretation, Biochemia Medica 2017; 25: 332-41.

12. Jakobsen J, Bysted A, Andersen R, et al. Vitamin D status assessed by a validated HPLC method: within and between variation in subjects supplemented with vitamin D3. Scand J Clin Lab Invest 2009; 69(2): 190-7.

13. Sempos CT, Vesper HW, Phinney KW, L, et al. Vitamin D status as an international issue : National surveys and the problem of standardization. Scand J Clin Lab Invest Suppl 2012; 243: 32-40.

14. Hutchinson K, Healy M, Crowley V, et al. Verification of Abbott 25-OH-vitamin D assay on the architect system. Pract Lab Med 2017; 7: 27-35.

15. Annema W, Nowak A, Von Eckardstein A, et al. Evaluation of the new restandardized Abbott Architect $\mathrm{OH}$ Vitamin D assay in vitamin D insufficient and vitamin D supplemented individuals. J Clin Lab Anal 2018; 32(4): e22328.

16. A. V. D. package insert 510k 25-OH D, Decision Summary Assay Only Template, vol. 510, pp. 1-17, 1825. 
17. Gören AC, Şahin G, Gümilcineli İ. Rapid and reliable 25$\mathrm{OH}$ vitamin D2 and 25-OH vitamin D3 measurements by multitasker LC-MS/MS. J Chem Metrol 2018; 12(1): 17-25.

18. Thacher TD, Clarke BL. Vitamin D Insufficiency. Mayo Clin Proc 2011; 86(1): 50-60.

19. Gallagher JC, Sai AJ. Vitamin D Insufficiency, Deficiency, and Bone Health. J Clin Endocrinol Metab 2015; 95: 2630-3.

20. Ekaterina Manuilova Andre Schuetzenmeister, Fabian Model, mcr: Method Comparison Regression. R package version 1.2.1., 2014, https://CRAN.R-project.org/package $=$ mcr.

21. Mark Stevenson with contributions from Telmo Nunes, Cord Heuer, Jonathon Marshall, et al. RStudio Team (2015). RStudio: Integrated Development for R. RStudio, Inc., Boston, MA URL http://www.rstudio.com/.

22. Dreier N, Lykkedegn S, Back $P$, et al. S-25-hydroxyvitamin $D$ and C3-epimers in pregnancy and infancy: An Odense Child Cohort study, Clinical Biochemistry 2017; (2): 1 .

23. Ozcan N, Ucar F, Arzuhal AE, et al. Evaluation of the analytical performance of Unicel DXI 800 for the Total 25 $(\mathrm{OH})$ Vitamin D measurements. Clin Biochem 2016; 49(6): 486-91.

24. Topçuoğlu C, Sezer S, Ercan $M$, et al. Evaluation of the analytical performance of the Beckman Coulter Unicel
DXI 800 Access Total 25(OH) Vitamin D immunoassay, Laboratoriums Medizin 2018; 42(5): 205-11.

25. WHO Scientific Group on the Prevention and Management of Osteoporosis 2003 Prevention and management of osteoporosis: report of a WHO scientific group. Geneva: World Health Organization 2000, Geneva, Switzerland.

26. Şezgin G, Ozturk G, Turkal R, Caykara B. Vitamin D Levels of Outpatients Admitted to a University Hospital in the Marmara Region of Turkey Over 3 Years. J Med Biochem 2019; 38; 181-7.

27. Vitamin $D$ deficiency in adults: Definition, clinical manifestations, and treatment UpToDate. Bess D.-H.: UpToDate Inc. https://www.uptodate.com/contents/vitamin-d-deficiency-in-adults-definition-clinical-manifestations-and-treatment (Accessed on March 31, 2019)

28. Cavalier E, Carlisi A, Bekaert A, et al. Analytical evaluation of the new Abbott Architect 25-OH vitamin $\mathrm{D}$ assay. Clin Biochem 2012: 45(6): 505-8.

29. Cavalier E, Lukas P, Bekaert A-C, et al. Analytical and clinical validation of the new Abbot Architect 25-OH D assay: fit for purpose? Clin Chem Lab Med 2017; 55(3): 378-84.

30. Shah RJ, Barker J, Petroczi A, et al. Misleading measures in Vitamin D analysis: A novel LC-MS/MS assay to account for epimers and isobars. Nutr J 2011; 10(1): 46. 